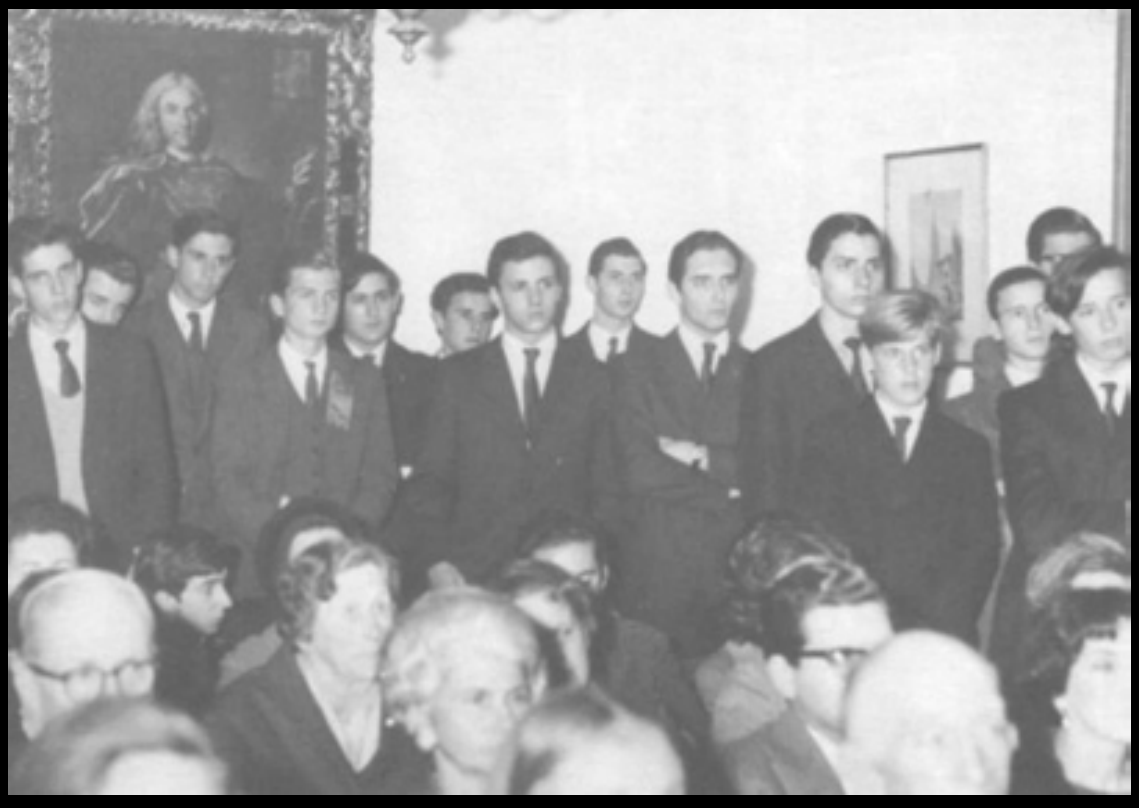

Acto inaugural de fundación de la «Sociedad Argentina de Defensa de la Tradición, Familia y Propiedad», 3 de abril de 1967. Fuente: http://www.pliniocorreadeoliveira.info/ GestaES_O201Argentina.htm\#.UvP5e_tS4-N 


\section{El grupo «Cruzada» - «Tradición Familia y Propiedad» (TFP) y otros emprendimientos laicales tradicionalistas contra los sectores tercermundistas. Una aproximación a sus prácticas y estrategias de difusión en los años sesenta \\ The "Crusade" group - "Tradition Family and Property" (TFP) and other traditionalist lay undertakings against the third-world sectors. An approach to their practices and dissemination strategies in the sixties \\ O grupo "Cruzada" - "Tradição, Família e Propriedade" (TFP) e outros empreendimentos laicais tradicionalistas contra os sectores terceiro-mundistas. Aproximação das suas práticas e estratégias de difusão nos anos sessenta}

\section{Elena Scirica}

Universidad de Buenos Aires

(Buenos Aires, Argentina)

elenascirica@yahoo.com.ar
Este artículo se enmarcó en el Proyecto UBACYT (2010-2012): «Identidades religiosas, sociabilidad y cultura política en la Argentina contemporánea», dirigido por Claudia Touris y financiado por la Universidad de Buenos Aires. Una versión preliminar del mismo, con el título «Grupos laicales tradicionalistas contra los sectores tercermundistas. Una aproximación a sus prácticas y estrategias de difusión durante el Onganiato» fue presentada en el Iv Simposio Internacional sobre Religiosidad, Cultura y Poder, organizado por el Grupo de Estudios sobre Religiosidad y Evangelización (GERE), en el Museo Roca, Ciudad Autónoma de Buenos Aires, del 29 al 31 de agosto de 2012.

\section{Resumen}

Esta contribución aborda una serie de estrategias desplegadas por círculos católicos laicos anticomunistas contra lo que consideraban como la irrupción del marxismo dentro de la Iglesia en Argentina en la década de 1960. En particular, se analizan las prácticas desplegadas por el grupo "Cruzada» convertido en "Tradición, Familia y Propiedad» (TFP). Para ello, se analizan diversos dispositivos, tales como libros, publicaciones periódicas, solicitadas, panfletos y volantes. A través de estos medios, los sectores intransigentes buscaron incidir tanto en la cúpula eclesiástica como en la opinión pública en general, por medio de una creciente homologación entre los términos «tercermundistas», «comunistas» $\mathrm{y}$ «terroristas». Ese accionar, en un escenario signado por una creciente conflictividad social, confrontación política y masiva participación ciudadana, contribuyó a la polarización de las posiciones, a la vez que reforzó la ligazón entre la religión y la política -o la instrumentación de una por la otra-.

\section{Abstract}

This contribution deals with a number of strategies deployed by lay Catholic circles against what they considered to be the emergence of Marxism in the Church in Argentina in the 1960s. In particular, the practices deployed by the "Crusade" group that later became "Tradition, Family and Property" (TFP) are analyzed. To this end, various kinds of materials are studied such as books, periodicals, pamphlets and flyers. Through these means, the hardliners sought to influence both the Catholic hierarchy and the general public opinion, through an increasing equal comparison of the terms "third-world", "communists" and "terrorists". That operation, in a scenario marked by an increasing social unrest, political confrontation and massive citizen participation, contributed to the polarization of positions, while reinforcing the link between religion and politics, -or the handling of one by the other-.

\section{Palabras clave}

tradición; familia y Propiedad; anticomunismo; integrismo; historia política argentina; Guerra Fría

\section{Keywords}

tradition; family and Property; anticommunism; fundamentalism; Argentina's political history; Cold War

\section{Resumo}

Esta contribuição aborda uma série de estratégias alastradas por círculos católicos laicos anticomunistas contra aquilo que achavam irrupção do marxismo dentro da Igreja na $\mathrm{Ar}-$ gentina na década de 1960. Em particular, analisam-se as práticas espalhadas pelo grupo "Cruzada" converso em "Tradição, Família e Propriedade" (TFP). Para isso, analisam-se diversos dispositivos tais como livros, publicações periódicas solicitadas, panfletos e folhetos. Através destes meios, os setores intransigentes buscaram incidir tanto na cúpula eclesiástica como na opinião pública em geral, por meio de uma crescente homologação entre os termos "terceiro-mundistas", "comunistas" e "terroristas". Esse acionar, em um cenário marcado por conflitualidade social crescente, confronto político e participação cidadã massiva, contribuiu para a polarização das posições, ao tempo que reforçou a ligação entre religião e política -ou a instrumentação de uma pela outra-.

\section{Palavras chave}

tradição; família e propriedade; snticomunismo, integrismo; história política argentina; Guerra Fria 


\section{Introducción}

En los últimos años, en Argentina surgieron renovados trabajos sobre las convicciones, las prácticas y las trayectorias de jóvenes católicos volcados a la militancia y al compromiso social con sectores tradicionalmente marginados $\mathrm{u}$ oprimidos. Sin embargo, el estudio de los laicos ultraconservadores e intransigentes no ha merecido la misma atención, más allá de algunos trabajos sobre núcleos puntuales ${ }^{1}$. Estas apreciaciones no suponen de ninguna manera encorsetar al catolicismo en dos grandes bandos, sino recalcar la existencia de dos polos dinámicos ubicados en un espectro mucho más matizado y complejo. A partir de estas consideraciones, en el marco de una investigación sobre grupos católicos contrarrevolucionarios visceralmente anticomunistas en la Argentina de los años sesenta, este artículo presentará determinadas estrategias desplegadas por algunos grupos laicales para afrontar el avance de los sectores tildados de progresistas, de tercermundistas y de lo que consideraban como la irrupción del marxismo dentro de la Iglesia. En efecto, ciertos núcleos intransigentes recurrieron a un amplio repertorio de prácticas orientadas a difundir sus convicciones e

1 La mención al catolicismo intransigente refiere a una postura reactiva frente a los valores del mundo moderno -tal como quedó asentado en la Syllabus, de Pío Ix (1864), y luego en la encíclica Pascendi, de Pío x (1907)- y la secularización de la sociedad. Una importante línea de estudios postula una matriz integralista común en gran parte del catolicismo argentino, caracterizada, entre otras facetas, por su antiliberalismo, su antimodernismo, su negativa a relegarse al ámbito de las prácticas religiosas particulares y su afán de penetración en la sociedad. Fortunato Mallimaci, El catolicismo integral en la Argentina. 1930-1946 (Buenos Aires: Biblos, 1988). Al respecto, coincidimos con Touris en la necesidad de delimitar las continuidades y las rupturas del modelo integralista en el catolicismo vernáculo. Para el período postconciliar debiera repensarse la noción de catolicismo integral, evaluando sus «alcances integrales ('catolicismo en toda la vida') y sociales por el lado de los tercermundistas, más que de la intransigencia de este grupo, ciertamente reconfigurada a partir del diálogo con las izquierdas». Claudia Touris, «Integrismos y profecía utópica en los imaginarios católicos de los años setenta», en Nuevos aportes a los estudios de la religión en las sociedades contemporáneas del Cono Sur, ed. Mariela Ceva y Claudia Touris (Buenos Aires: Lumiere, 2011), 107. Se puede encontrar una evaluación de los conocimientos sobre los principales núcleos católicos anticomunistas e intransigentes en Elena Scirica, «Núcleos católicos anticomunistas bajo el Onganiato. Encuentros y desencuentros», en Primer Taller de Análisis y discusión sobre el Onganiato, ed. Florencia Osuna y Valeria Galván (Los Polvorines, Prov. de Buenos Aires: Universidad Nacional de General Sarmiento, 2012). incidir tanto en la cúpula eclesiástica -instando a los obispos para que condenaran a los sectores tercermundistas y denunciando a los prelados afines o contemporizadores- como en la opinión pública en general -por medio de una creciente homologación entre los términos «tercermundistas», «comunistas» y «subversivos»-. Interesa recalcar, pues, que su apuesta no solo los llevó a abroquelarse con los tradicionales guardianes del orden -fundamentalmente, las FF.AA, tal como es un lugar común señalar-, sino que también acentuaron su actividad en diversos espacios de la sociedad civil con miras a librar la batalla en la conciencia de la población.

¿Qué sectores del catolicismo intransigente participaron en este embate? ¿Cuáles eran sus principales inquietudes al realizarlo? ¿A través de qué tipo de espacios y soportes lo hicieron? ¿Cómo los difundieron? ¿Quiénes eran los principales destinatarios? A partir de estos interrogantes, en este artículo focalizaremos la atención en el núcleo aglutinado en torno a la revista Cruzada y su transmutación en la «Sociedad Argentina de Defensa de la Tradición, la Familia y la Propiedad» en el transcurso de los años sesenta, por una parte, y en las presiones ejercidas por diversos sectores intransigentes en rechazo del Movimiento de los Sacerdotes para el Tercer Mundo (мsтм) y del aumento de la protesta social durante el gobierno dictatorial presidido por el general Onganía (1966-1970), por otra. Este doble abordaje se motiva porque interesa analizar tanto la continuidad en las prácticas de algunos sectores, como la proliferación de acciones concurrentes que se desplegaron en un marco de conflictividad creciente. En este desarrollo, señalaremos el empleo de numerosas modalidades de difusión para afrontar el avance de la visualizada «revolución anticristiana» dentro y fuera de la Iglesia. Estas dan cuenta del recurso a múltiples formas de comunicación política que incluyeron soportes tales como libros, publicaciones periódicas, solicitadas, emisiones radiales, pintadas, carteles y panfletos, entre otros, además de la realización de encuentros, conferencias y disertaciones. Ese accionar, en un escenario signado por una creciente conflictividad social, confrontación política y masiva participación ciudadana, contribuyó a la polarización de las posiciones a la vez que 
reforzó la ligazón entre la religión y la política -o la instrumentación de una por la otra-.

\section{De Cruzada a «Sociedad Argentina de Defensa de la Tradición, la Familia y la Propiedad»: estrategias y modalidades de difusión}

Una de las organizaciones más visibles de laicos católicos tradicionalistas e intransigentes en el país rioplatense fue la «Sociedad Argentina de Defensa de la Tradición, la Familia y la Propiedad» (en adelante, TFP). En rigor, este emprendimiento aglutinó originariamente a jóvenes de origen patricio en torno a la revista Cruzada. Su máximo referente fue Cosme Béccar Varela (h), un abogado miembro de una distinguida familia argentina ${ }^{2}$.

Cruzada, cuyo primer número apareció en 1956, se destacó no solo por su mentada defensa de la «verdad católica» y de las «tradiciones argentinas», sino también por su férrea salvaguarda del derecho de propiedad y su incólume posición anticomunista ${ }^{3}$. Tal como afirmaba un díptico de presentación de ese medio:

Cruzada es una revista católica fundada para defender los valores básicos de nuestra civilización. Entre esos valores se cuentan la familia, fundada sobre el matrimonio indisoluble; la propiedad privada y las

2 Su padre, Cosme Beccar Varela, también era abogado y empresario, vicepresidente de la cervecería Quilmes y asesor del City Bank. Por otra parte, había participado de los «Cursos de Cultura Católica» que, organizados a modo de una universidad de élite, surgieron en 1922 con el propósito de construir y difundir una «alta cultura católica» que entablara una lucha ideológica contra el positivismo y el naturalismo recurriendo a la doctrina integralista de inspiración tomista. Loris Zanatta, Del Estado liberal a la nación católica (Bernal: Universidad Nacional de Quilmes, 1996), 44-46. Su abuelo, Horacio Beccar Varela, abogado, había sido, entre otras actividades, ministro de Agricultura en el gobierno dictatorial del general José Félix Uriburu. Gustavo Dalmazo, «El tradicionalismo ante la apertura política en la Revolución Argentina», IV Jornadas Nacionales de Historia Moderna y Contemporánea (Resistencia, Universidad Nacional del Nordeste, 2004). Otras referencias en Horacio Verbitsky, La violencia evangélica (Buenos Aires, Sudamericana, 2008), 98-99. Para la autorepresentación de tfp, http//www.pliniocorreadeoliveira.info/GestaES_0000Indice. htm (consultado el 30 de julio de 2012).

3 «A la derecha de Dios», Primera Plana [Buenos Aires], 23 de mayo, 1967, 16-17; Ianko Bett, «Una revolución que nos afecta: A Revista Cruzada e o golpe militar de 1964 no Brasil», en Actas de las Terceras Jornadas de Religión y Sociedad en la Argentina contemporánea y países del Cono SUr (III RELIG-AR SUR)/v Jornadas de Religión y Sociedad en Argentina, ed. Claudia Touris y María Florencia Contardo (Buenos Aires: RELIG-AR ed., 2013). legítimas desigualdades sociales, especialmente atacadas por la acción subrepticia del socialismo y por las embestidas brutales y subversivas del comunismo ${ }^{4}$.

Pero lo singular de este medio y sus seguidores no fueron, simplemente, los contenidos proclamados, sino las acciones realizadas para promocionarlos. Así, en sus inicios la revista solía ser difundida en determinados lugares públicos, tales como la calle Florida de la Ciudad de Buenos Aires -una peatonal con prestigiosos comercios e instituciones bancarias- o los atrios de iglesias céntricas de la capital. A partir de 1964, cuando la publicación denunció con firmeza el plan de lucha sindical organizado por la Confederación General del Trabajo (CGT), cuestionó las declaraciones de sacerdotes cordobeses que -en clara discordancia con el arzobispo de la arquidiócesisse solidarizaron con la lucha sindical. Además, se opuso con vigor a un proyecto de ley de reforma de la empresa presentado en el Parlamento por el bloque de diputados de la Democracia Cristiana, al que tildó de estatizante y socializante; el grupo cobró mayor notoriedad y actuó con bríos renovados. En este marco, Beccar Varela redactó una «Interpelación a los diputados demócrata-cristianos» en la revista Cruzada destinada a difundirse no solo en las librerías y periódicos del centro capitalino, sino también en todo el país vía correo postal. Al mismo tiempo, bajo la forma de folleto -editado con la cooperación de sectores empresariales, según declararon los miembros de la TFP-, los integrantes de ese núcleo realizaron una intensa campaña de difusión en la calle Florida, donde recolectaron firmas en rechazo a la iniciativa ${ }^{5}$.

4 Díptico de presentación de Cruzada incluido en un cuadernillo editado por el grupo en 1965.

5 Relato crítico sobre la interpelación de Cruzada, en Arturo Armada; Norberto Habegger y Alejandro Mayol, Los católicos posconciliares en la Argentina (Buenos Aires: Galerna, 1970), 152-154 y 252-258; Relato oficial de TFP: www.pliniocorreadeoliveira.info/ GestaES_0201Argentina.htm (consultado el 31 de julio de 2012). La forma de solicitadas públicas se tornará práctica recurrente en el grupo. Así, tras el documento «La CGT en marcha hacia el cambio de estructuras», elaborado por esa central sindical en agosto de 1965, Cruzada respondió con otra solicitada inquiriendo sobre lo que consideraba como coincidencias entre ese documento y los lineamientos del marxismo. Véase «Interpelación a los actuales dirigentes del peronismo», La Nación [Buenos Aires], 20 de agosto, 1965: 5. Sectores social cristianos respondieron con la solicitada «La Iglesia y el cambio social», La Nación [Buenos Aires], 8 de septiembre, 1965: 3 . 
De este modo, desarrollaron una intensa acción pública en la que confluyeron diversas modalidades de transmisión, tales como publicación de folletos, solicitadas públicas y recolección de firmas. Estas prácticas, a su vez, fueron acompañadas por la colocación de pancartas y reparto de volantes en espacios cada vez más variados. Así, combinaron una doble estrategia. Por una parte, por su origen social, valoraciones y redes de vinculaciones, su prédica tuvo mayor despliegue y anclaje en espacios selectos. En este sentido, el grupo difundió sus folletos y libros en los stands que dispuso en las exposiciones anuales de la Sociedad Rural Argentina -asociación privada que congrega y representa a los principales terratenientes del país con intereses en la agricultura, la ganadería y actividades industriales derivadas- $y$ en otras muestras agropecuarias de diversas provincias, a la vez que no eran extrañas las disertaciones de su presidente en algunas sedes del exclusivo Jockey Club $b^{6}$. Por otra parte, de manera progresiva, los miembros y simpatizantes de Cruzada establecieron formas comunicacionales orientadas a llegar al "gran público». Cabe destacar, asimismo, que en sus campañas recurrieron al empleo de los símbolos con miras a atraer la atención e instituirse como un núcleo distintivo. Así, sus actos sobresalieron por la presencia de estandartes rojos con un león dorado de fondo -pendón característico del grupo-, portados por sus acicalados miembros, quienes además llevaban vistosas capas coloradas. En Argentina, aquel emblema se adoptó por primera vez en 1966, en la campaña realizada para difundir la obra «Trasbordo ideológico inadvertido y Diálogo», del creador y líder de la TFP en Brasil, Plinio Correa de Oliveira. Cabe señalar que este abogado de origen paulista fue una figura emblemática de ciertos sectores católicos contrarrevolucionarios que denunciaban el avance de la revolución mundial de carácter atea y anticristiana, que en su perspectiva se habría iniciado con la Reforma Protestante y el Renacimiento, para continuar con el iluminismo, la Revolución Francesa y, en el siglo xx, con la Revolución Rusa y el

6 Esta presencia es reconocida tanto por el sitio web oficial del grupo como por la prensa periódica y por sus detractores. «Hubo incidentes en la ciudad de Santa Fe», La Prensa [Buenos Aires], 4 de mayo, 1967, 10. avance comunista, tal como Plinio lo asentó en su clásica obra Revolución y contrarrevolución (1959). Acérrimo defensor del derecho de propiedad y furibundo crítico de la reforma agraria, Correa de Oliveira accedió a una banca en el senado brasileño tras el derrocamiento de Joao Goulart. Pero antes, en 1960, fundó la TFP junto a importantes terratenientes paulistas y pronto esa organización se expandió a Chile -sus promotores, aglutinados en torno a la revista Fiducia, expresaron su oposición a las reformas emprendidas por Eduardo Frei-, Argentina -donde el grupo de Cruza$d a$ organizado por Béccar Varela se subsumió en la TFP-y otros países de América y del mundo ${ }^{7}$. El libelo de la figura máxima de la TFP -redactado al año siguiente de la encíclica Eclessiam Suam (1964) y su llamado al diálogo interreligioso y entre la Iglesia y el mundo- denunciaba lo que en su perspectiva era el recurso del «diálogo» como una estrategia propia de la guerra psicológica montada por el marxismo para introducir el relativismo entre los católicos y corroer las verdades esenciales en el seno de la Iglesia, lo que constituía un peligroso avance de la revolución anticristiana. Por tal motivo -aunque cuidándose de señalar que el sentido del «diálogo» como palabra talismán empleada por los comunistas se diferenciaba del otorgado por el Papa en la Ecclesiam Suam-denunciaba el ecumenismo y la coexistencia pacífica como operaciones de «trasbordo ideológico», a la vez que reclamaba una perentoria lucha contra el comunismo ${ }^{8}$. Este tipo de reflexiones, consustanciadas con la

7 En vista de que un análisis específico del grupo y de su fundador excede los objetivos de este trabajo, puede consultarse una obra biográfica con una fuerte carga laudatoria en Roberto Mattei, El cruzado del siglo xx. Plinio Correa de Oliveira (Madrid: Ediciones Encuentro, 1997). En Argentina escasean los trabajos referidos a la tfp y su líder. En Brasil, entre otros, véase la reciente y exhaustiva investigación de Gizele Zanotto, TFP. Tradição, Família e Propiedade. As idiosincrasias de um movimento católico no Brasil, 1960-1995 (Passo Fundo: Méritos Editora, 2012).

8 La portada del folleto tiene el agregado mecanografiado, a modo de subtítulo: «La más reciente estratagema comunista para conquistar la opinión mundial». En la contraportada se aclara que se trata de una Separata del $n .^{\circ} 60$ de la revista Cruzada, con censura eclesiástica, y que el original fue publicado en Catolicismo, con Imprimatur del Obispo Diocesano de Campos, Antonio de Castro Mayer. Este obispo, descollante por su prédica anticomunista, se opuso a las innovaciones implementadas tras el Concilio y en 1969 dirigió una carta a Paulo vi para cuestionar el Novus Ordo Misae (la norma general para la misa). Véase Plinio Correa de Oliveira, Trasbordo ideológico inadvertido y Diálogo (Buenos Aires: Cruzada, 1966).

El grupo «Cruzada» - «Tradición Familia y Propiedad» (тғр) y otros emprendimientos / Elena Scirica / 69 
convicción de una creciente infiltración marxista en la Iglesia, constituirán una de las bases sobre las que los sectores intransigentes montarán la denuncia de los sectores tercermundistas en Argentina y de la teología de la liberación en el continente.

En 1967 el grupo Cruzada, liderado por Cosme Beccar Varela (h), se convirtió en la versión argentina de la TFP creada en Brasil por Plinio Correa de Oliveira. Huelga señalar que esta conversión no significó un cambio de ideales ni de prácticas, así como tampoco implicó un traspaso de integrantes. Se trató, sin más, de la adopción de un nuevo apelativo producto de la afinidad de convicciones y del creciente acercamiento y admiración que, desde los años anteriores, los jóvenes católicos de Cruzada y su principal referente habían experimentado con el mentor de la TFP. Ese entusiasmo había sido provocado no solo por la lectura de obras claves del referente brasileño, tales como Revolución y contrarrevolución (1959) o La libertad de la Iglesia en el Estado comunista (1963) -reproducida en Cruzada-, sino también por la participación en espacios comunes de análisis, debate y denuncia que se remontaban a comienzos de los años sesenta.

Durante el período en que esa confluencia se mantuvo, la versión argentina de ese núcleo continuó con las estrategias de difusión públicas reseñadas, a la vez que articuló algunos de sus principales cometidos con los realizados por otras seccionales de la TFP, sobre todo de Brasil, Chile y, luego, Uruguay. Respecto de esta operatoria, cabe señalar que si bien cada TFP constituía una asociación independiente, su identificación con la sociedad madre las integraba en una suerte de red transnacional que eventualmente -sobre todo, en la segunda mitad de la década de 1960- organizaba acciones comunes aunque no mantenía un espacio orgánico de reuniones periódicas.

\section{Puentes y vasos comunicantes}

Si bien este emprendimiento tenía puentes y vasos comunicantes con otros sectores del catolicismo intransigente, se diferenciaba -entre otros aspectos- por su arropo de dispositivos y herramientas para actuar en una sociedad masificada -lo cual no era incompatible con el hecho de que el ingreso como miembro a la TFP era muy restrictivo- y por su interés en ser visibilizado como núcleo de acción y opinión -práctica también desplegada por otros grupúsculos de breve duración- ${ }^{9}$. Otros círculos afines a ese ideario, en cambio, optaban por desenvolverse y canalizar sus emprendimientos y apuestas en espacios selectos o poco visibles. Tras esa estrategia se hallaba la convicción de que las capas dirigentes y las consideradas «élites naturales» eran las únicas capacitadas para actuar y decidir. Aunque la TFP, imbuida de una visión aristocrática, compartía esta apreciación, no por ello desestimaba el despliegue en el espacio público con miras a operar como grupo de presión, ya que partía del reconocimiento de la importancia de los símbolos $\mathrm{y}$ de las acciones visibles para actuar en el mundo contemporáneo y encausar las orientaciones de las masas. Al respecto, es factible que en esta operatoria estuviera presente el halo primigenio de la Acción Católica y su cometido como actividad organizada de los laicos en procura de Instaurare Omnia in Christo, aunque ahora se desarrollara según una nueva estructura organizativa autónoma de la jerarquía eclesiástica ${ }^{10}$.

En Argentina, después del golpe de Estado del 28 de junio de 1966 que dio inicio al gobierno militar de la autodenominada «Revolución Argentina» (1966-1973), cobró dimensión pública la presencia de diversos núcleos católicos que actuaban en el entorno del flamante presidente Juan Carlos Onganía -a cuya asunción asistió

9 Ciertos sectores del catolicismo intransigente se consideraban distantes de la TFP y de Beccar Varela, a quien juzgaban como «liberal» o de «derecha» por su actuación en la política y por su alineamiento irrestricto con los intereses de los sectores propietarios sin incorporar menciones de sensibilidad social o ambages paternalistas. Véase Héctor Hernández, Sacheri. Predicar y morir por la Argentina (Buenos Aires: Vórtice, 2007), 53. Por su parte, los miembros de Cruzada y de la TFP abjuraban de los liberales, a quienes juzgaban por laicistas.

10 Si bien el Papa Pío x (1903-1914) estableció las bases organizativas de la Acción Católica (AC), pensada como una reorganización de los movimientos de laicos a fin de que incidieran en una recristianización de las costumbres y de la vida pública siguiendo las directrices de los obispos y de Roma, fue Pío xI (1922-1939) quien le dio forma, definiéndola como «participación de los laicos en el apostolado jerárquico». Sin embargo, esa religiosidad de combate que procuraba reconquistar el mundo para Cristo fue complejizándose y dando lugar a una creciente autonomía del laicado. José Zanca, Los intelectuales católicos y el fin de la cristiandad. 1955-1966 (Buenos Aires: Fondo de Cultura Económica-Universidad de San Andrés, 2006), 15-17; 19-27 y 32-35. 
Antonio Caggiano, a la sazón cardenal primado y arzobispo de Buenos Aires-. Entre ellos, algunos analistas destacaron la impronta del nacionalismo hispánico, tecnocrático y desarrollista del Ateneo de la República, el fervor de los participantes de los Cursillos de la Cristiandad, el ultramontanismo de los Cooperadores Parroquiales Cristo Rey y el comunitarismo de la Ciudad Católica (en adelante, $\mathrm{Cc})^{11}$. Si bien el modus operan$d i$, las convicciones y la impronta de esos grupos se diferenciaba en cada caso, interesa señalar que ninguno de ellos tenía una operatoria orientada a la difusión masiva (a tono con lo señalado anteriormente) ${ }^{12}$. Según Rouquié, en tanto estos núcleos pretendían proveer programas y personal político al gobierno militar, otros grupúsculos, como la TFP, intentaban usurpar en su beneficio la expresión pública de las opiniones ${ }^{13}$. En este sentido, más allá de los matices de cada uno, no se trataba de sectores enfrentados ni incomunicados entre sí-de hecho, hay indicios de participación en espacios comunes, a pesar de sus discrepancias- sino de cierta diferenciación de funciones ${ }^{14}$. Así, bajo una dictadura que había

11 De ello se hicieron eco, con cierta sorpresa, diversos medios periodísticos que habían apoyado el golpe de Estado. Vg, «Católicos. Colaboración con el gobierno», Primera Plana [Buenos Aires], 12 de julio, 1966, 14; «Los católicos y el poder», Primera Plana [Buenos Aires], 16 agosto, 1966, 16-21. También lo reseñaron Rogelio García Lupo, «Los Cursillos de Cristiandad: partido secreto de Onganía», en Mercenarios y monopolios en la Argentina. De Onganía a Lanusse: 1966-1973 (Buenos Aires: Legasa, 1984), 11-27 y Gregorio Selser, El Onganiato. Tomo I (Buenos Aires, Hyspamérica, 1986), 33-50 y 221-234; Gregorio Selser, El Onganiato. Tomo II (Buenos Aires: Hyspamérica, 1986), 11-18. Se encuentra un relevamiento analítico de los conocimientos sobre estos grupos, en Scirica, «Núcleos católicos anticomunistas».

12 Alain Rouquié, «La tentación del catolicismo nacionalista en la República Argentina», en Autoritarismo y democracia. Estudios de política argentina, ed. Alain Rouquié. (Buenos Aires, Edicial, 1994), 105-111 y Alain Rouquié, Poder militar y sociedad política en la Argentina. T. II (Buenos Aires: Hyspamérica, 1986); 259-261; Paul Lewis, «La derecha y los gobiernos militares. 1955-1983», en La derecha argentina. Nacionalistas, neoliberales, militares y clericales, ed. David Rock et al. (Buenos Aires: Javier Vergara, 2001), 342-348.

13 Rouquié, «La tentación del catolicismo nacionalista», 112-114.

14 A modo de ejemplo, la «Ciudad Católica» (cc), estructurada en pequeñas células y caracterizada inicialmente por el sigilo de su accionar, reprodujo en su boletín Verbo, con la aclaración de «Su lucha es la nuestra», la Introducción de «Revolución y contrarrevolución», de Plinio Correa de Oliveira, publicada en 1959 en la revista Catolicismo, de Brasil. Verbo, n. 3 (julio 1959): 52-56; años más tarde reprodujo, del líder brasileño de la TFP, «Covadonga, ¿monumento a una epopeya negativista?» Verbo, n. ${ }^{\circ}$ 61-62 (junio/julio 1966): 25-30. La pertenencia a la cc, orientada a formar «cuadros» para que actuaran en la sociedad, no ex- disuelto los partidos políticos (amén de haber confiscado sus bienes) y establecido una férrea censura de prensa, los jóvenes activistas católicos enrolados en núcleos como TFP gozaron de amplia libertad para manifestarse en espacios públicos, desplegar sus pancartas, distribuir panfletos y vender sus publicaciones -lo cual brinda sospechas de cierto aval policial e incluso, para algunos autores, de la protección del Servicio de Informaciones del Estado (sIDE) ${ }^{15}$. De este modo se entiende que, a pesar de su debilidad numérica -en 1967, una reconocida publicación de la época indicaba que la TFP en Argentina contaba con unos mil simpatizantes y una cincuentena de activistas, aunque probablemente el cálculo esté rebajado por el tono despectivo del articulista- ${ }^{16}$, las campañas emprendidas alcanzaran gran repercusión -alentadas también por las vistosas estrategias adoptadas-.

Entre dichas estrategias se destacaron las realizadas tanto contra las propuestas de reforma agraria $u$ otras que pudieran afectar a los sectores propietarios, como contra la supuesta infiltración comunista en el espacio eclesiástico. Claro está que este accionar no resultó indiferente en el seno del catolicismo. Así, amén de las controversias públicas generadas durante 1964 y 1965 -algunas de las cuales fueron reseñadas- y de las distintas posiciones de cada uno de los miembros del episcopado, hubo prelados que marcaron las diferencias entre las afirmaciones de ese núcleo y las de la Iglesia. A modo de ejemplo, en 1967, en pleno auge de la llamada «Revolución Argentina» -mientras cobraban mayor fuerza las divergencias

cluía la participación en otros círculos o núcleos de acción en pos de la «irradiación de la Verdad» y la instauración de la «Realeza Social de Jesucristo». Elena Scirica, «Visión religiosa y acción política. El caso de Ciudad Católica-Verbo en la Argentina de los años sesenta», PROHAL MONOGRáfICo, Revista del Programa de Historia de América Latina 2, n. 2 (2010), 26-56.

15 Rouquié, «La tentación del catolicismo nacionalista», 112. El general Eduardo Señorans, al frente de la side y reconocido anticomunista, tuvo contactos también con el núcleo Ciudad Católica. Scirica, «Visión religiosa y acción política», 47-48. La actuación y campañas de la TFP daban lugar, en ocasiones, a reyertas públicas a raíz de la oposición y el malestar que causaban en diversos sectores de la sociedad civil. Ejemplo de ello, «Hubo incidentes en la ciudad de Santa Fe», La Prensa [Buenos Aires], 3 de mayo, 1967, 10.

16 «A la derecha de Dios», Primera Plana [Buenos Aires], 23 de mayo, 1967, 17.

El grupo «Cruzada» - «Tradición Familia y Propiedad» (TFP) y otros emprendimientos / Elena Scirica / 71 
en el campo católico ${ }^{17}$ - monseñor Alberto Devoto, obispo de Goya (Corrientes), destacó que los jóvenes de Cruzada «no representan de manera alguna el pensamiento de la Iglesia» y que sus escritos «deforman las enseñanzas de la Iglesia en materia social» ${ }^{18}$. No resulta casual que este comunicado proviniera de ese prelado. En efecto, se trata del mismo obispo que dio a conocer la versión francesa del «Manifiesto de los 18 Obispos del Tercer Mundo", cuya posterior traducción y puesta en circulación constituyó un importante hito en la conformación del MSTM en el país ${ }^{19}$.

\section{Campañas. Algunas inquietudes presentes y espacios de denuncia}

En 1968, en forma coetánea con el primer encuentro del mstm y en vísperas de la in Asamblea del Consejo Episcopal Latinoamericano (cELAm) en Medellín, que adoptó una línea de catolicismo liberacionista y de opción por los pobres -sucesos contemporáneos con las crecientes divergencias en el seno del catolicismo, con la

17 El Concilio Vaticano II (1962-1965) acentuó las disensiones latentes en el catolicismo desde tiempo atrás y detonó una serie de tensiones que derivaron en una suerte de «guerra social entre católicos». Según Zanatta, la identificación entre el ideario nacional y el ser católico forjada en las primeras décadas del siglo xx repercutió en una creciente superposición entre conflictos intraeclesiásticos y conflictos políticos. Touris ha señalado que, en el caso latinoamericano, el Concilio no derivó en una autonomización entre las esferas religiosa y política, sino en un reforzamiento de la ligazón entre ambas e, incluso, «las filiaciones políticas pesaron más que las religiosas al definir la dialéctica amigo/enemigo». La polarización y politización de posiciones en la sociedad argentina atravesó a todos los sectores y fue común que la divergencia de proyectos se trazara en términos excluyentes, a través de un planteo por el cual se estaba con la Iglesia vinculada al poder o con la Iglesia de los pobres. Roberto Di Stéfano y Loris Zanatta, Historia de la Iglesia Argentina (Buenos Aires: Grijalbo Mondadori, 2000), Cap. Iv; Touris, «Integrismos y profecía utópica», 112; Juan Cruz Esquivel, Detrás de los muros. La Iglesia católica en tiempos de Alfonsín y Menem. 1983-1999 (Buenos Aires: Universidad Nacional de Quilmes, 2004), 80-81.

18 El Litoral [Corrientes], 19 de mayo, 1967. Las respuestas de la TFP quedaron plasmadas en ese mismo periódico en las ediciones de 4 y 5 de julio de ese año; también en el vespertino La Razón, [Buenos Aires], 7 de julio, 1967. Este tipo de posiciones y las diferencias entre los prelados se expresaron en la Asamblea General de la Conferencia Episcopal de noviembre de 1966, cuando el obispo de Goya expresó su inquietud por la revista Cruzada. Archivo Devoto en Verbitsky, «La violencia evangélica», 265-266.

19 Sobre la historia y el despliegue de ese colectivo sacerdotal hay una amplia bibliografía. Sobre el estado actual de las investigaciones sobre la radicalización política, Touris, «Integrismos y profecía utópica». visible radicalización política y social en naciones cercanas, y con el clima de revueltas expresado en las protestas estudiantiles y obreras en Europa y en nuestro continente-, la TFP de Brasil, en una acción concertada con la de Argentina, Chile y Uruguay, emprendió una campaña masiva en contra de los «eclesiásticos y laicos favorables al comunismo» ${ }^{20}$. Con este empeño, dirigió un «Reverente y filial mensaje al Papa Paulo vI» en el que manifestó su inquietud y solicitó que adoptase medidas eficaces para eliminar a una

[...] minoría organizada de eclesiásticos y laicos [que] difama a la generalidad de los Obispos y Sacerdotes de la Argentina y de toda la América Latina, acusándolos de retrógrados y sin conciencia [...y] quiere instaurar una tiranía política, social y económica que, a ejemplo de Fidel Castro [...] empiece a confiscar las propiedades agrarias y urbanas, así como las empresas industriales y comerciales, $y$ acabe por implantar oficialmente el comunismo ${ }^{21}$.

Este pedido fue acompañado por una intensa campaña de recolección de firmas que, según sus promotores, logró la adhesión de más de 260.000 personas en Argentina y alrededor de 2.000 .000 en Sudamérica (la mayor cantidad de rúbricas se obtuvo en Brasil $)^{22}$. De los enunciados de esta campaña surgía, pues, una visible homologación entre las corrientes renovadoras del catolicismo volcadas al compromiso social y el avance del comunismo en el continente. Asimismo, a tono con una inquietud madre de la TFP, el temor a la confiscación de propiedades aparecía recalcado, lo cual -más allá de los resonantes ecos que en el continente tuvo la Revolución Cubana y de la creciente radicalización de algunos emprendimientos vinculados con el catolicismo- resulta un tanto desproporcionado respecto de las demandas e inquietudes

20 Volante de TFP proporcionado por José María Meisegeier S.J. (padre Pichi). Llevo conmigo un inmenso reconocimiento a este sacerdote, fallecido en diciembre de 2011.

21 Volante de TFP. Firman por el Consejo Nacional de tFP Cosme Beccar Varela (h), Carlos Federico Ibarguren y Julio C. Ubbelohde.

22 Según la versión oficial de la TFP, en la Argentina firmaron, entre otras figuras relevantes, los arzobispos de Paraná, monseñor Adolfo Tortolo, de Corrientes, monseñor Francisco Vicentín, y de Mendoza, Alfonso Buteler. También rubricaron el pedido el ministro del Interior, Guillermo Borda y el comandante del primer cuerpo del Ejército, general Gustavo Martínez Zuviría. En Brasil, el texto del petitorio fue publicado en Catolicismo № 212/214 de agosto/octubre de 1968 y en numerosos periódicos, y logró la adhesión de más de un millón y medio de personas. 
que inspiraban, en ese entonces, a gran parte de la constelación tercermundista en Argentina, no comprometida en ese entonces con la lucha arma$\mathrm{da}^{23}$. Por otra parte, en dicho pedido, este núcleo de laicos que actuaba con autonomía de la jerarquía -lo que no implica desconocer la existencia de vínculos informales con ciertos eclesiásticosse arrogaba la lectura de la «verdadera» doctrina de la Iglesia por oposición a la de la denominada «minoría» que «difama». Si bien el Concilio Vaticano II había brindado mayor protagonismo a los laicos, el accionar de la TFP no se correspondía con una renovación de la presencia pastoral en nuevos lugares del apostolado. Más bien, podría entenderse como una renovación del espíritu belicoso y de cruzada que había caracterizado el despliegue del catolicismo integral desde la década de 1930, aunque, ahora, por fuera de la jerarquía y en un nuevo escenario político, social y religioso en el que plasmaban una sólida práctica militante. En esta línea, incluso, cabría reflexionar respecto de si el grupo en estudio no realizaba, en alguna medida, cierta utilización de su adscripción religiosa en función de sus inquietudes primordiales vinculadas con la defensa del statu quo.

En Argentina, esa campaña había sido precedida y acompañada por otras iniciativas orientadas tanto a la difusión de la TFP como a la denuncia de idearios, actores y prácticas vinculadas con la creciente radicalización católica. Así, a tono con el modus operandi de esa organización, el «hacer campaña» implicaba, junto con la publicación de solicitadas, la realización de conferencias y el armado de petitorios, y el salir a las calles arropados con las vistosas capas y estandartes para

23 Si bien hubo algunas experiencias en Argentina, como la nucleada en torno a la revista Cristianismo y Revolución, en la que confluyeron cristianos y marxistas y quedó plasmado el horizonte revolucionario de la época, otros sectores tercermundistas no alcanzaron ese nivel de radicalización. Retomamos, de Claudia Touris, el término «constelación» para destacar la amplia gama de actores, ideas y prácticas incluidas en lo que usualmente se reconoce como «tercermundistas». Touris, «Integrismos y profecía utópica», 106-107. También Claudia Touris, «Sociabilidad e identidad político-religiosa en los grupos católicos tercermundistas en la Argentina (1966-1976)», en Miradas sobre la historia social en la Argentina en los comienzos del siglo XXI, ed. Beatriz Moreyra, y Silvia Mallo (Córdoba-La Plata: Centro de Estudios Históricos «Prof. Carlos S.A. Segreti». Centro de Estudios de Historia Americana Colonial (CEHAC) Facultad de Humanidades y Ciencias de la Educación. Universidad Nacional de La Plata, 2008), 763-783. distribuir volantes, vender folletos y dar a conocer sus visiones de manera pública. En esa operatoria, la distribución de panfletos, que suponía un contacto directo con la gente, era práctica cotidiana. Una evaluación de estos muestra que no se trataba de simples impresos consignistas ${ }^{24}$. Por el contrario, imbuidos de una convicción férrea, portaban un estilo informativo combinado con elementos persuasivos y provocativos para llegar a los interpelados, con enunciados claros y específicos. En su argumento, además, había acusaciones y denuncias concretas que llamaban a los destinatarios a estar alertas y reaccionar frente al avance de lo rotulado como «blasfemia», «incitación a la violencia» $y$, en definitiva, prolegómenos del avance hacia el «yugo comunista». Este tipo de inscripción o marca negativa variaba de acuerdo con la ocasión. En efecto, los volantes - por su propia naturaleza- son de índole transitoria, cuasi efímera, pues están enlazados con la lógica de la lucha política. Se hacen pensados para la escucha contemporánea y en su elaboración y distribución se busca llamar la atención inmediata del receptor, a quien se pretende persuadir. Así, por ejemplo, tras la edición del libro de Norberto Habegger rotulado Camilo Torres el cura guerrillero -en referencia al sacerdote colombiano que optó por la lucha $\operatorname{armada}^{25}-$ la TFP emitió un volante. Este impreso, de marzo de 1968, estaba titulado «R. P. ALEJANDRO MAYOL», en la primera línea, seguido por «R. P. CARLOS MUGICA» en la segunda, y el copete, subrayado, «P. Alejandro Mayol, apologista del sacerdote-guerrillero Camilo Torres» ${ }^{26}$.

24 La mayor parte de los volantes a los que se tuvo acceso fueron facilitados por el padre Pichi (ver nota 20), quien los organizó de manera cronológica y adjuntó una mención sobre los espacios y escenarios en donde tuvieron lugar. Algunos de ellos y reflexiones al respecto, también en Ricardo de Titto, Voces en las calles. Los volantes políticos en la historia argentina (Buenos Aires: Aguilar, 2007), 11, 271, 313.

25 En la segunda mitad de los años sesenta, los sectores católicos consustanciados con el ideario liberacionista y las acciones proféticas ensalzaron la imperiosa necesidad de un cambio de estructuras económico-sociales para terminar con la situación de explotación, opresión y exclusión de los sectores más débiles y carenciados. En este marco, el sacerdote colombiano que optó por la vía guerrillera, Camilo Torres, se constituyó en una figura ícono. Norberto Habegger, Camilo Torres, el cura guerrillero (Buenos Aires: A. Peña Lillo, 1967).

26 Los sacerdotes argentinos Carlos Mujica y Alejandro Mayol fueron figuras relevantes del Movimiento de Sacerdotes por el Tercer

El grupo «Cruzada» - «Tradición Familia y Propiedad» (TFP) y otros emprendimientos / Elena Scirica / 73 
El impreso -dedicado en su mayoría al primero de los sacerdotes referidos por haber prologado el libro en cuestión- tenía en apariencia un carácter informativo, aunque estaba intercalado con una suerte de análisis de ese contenido para ejercer una acción persuasiva sobre el lector del libelo. A través de esas reflexiones, se filtraba la denuncia que iba adquiriendo un carácter creciente para, finalmente, realizar una apelación a la acción contra esa situación. En este sentido, la estructura era simple. Comenzaba con oraciones breves en las que se indicaba la diócesis en la que ejercía el eclesiástico aludido, su origen social -con un señalamiento expreso de que «Pertenece a una distinguida familia de la sociedad porteña»-, actividades por las que era conocido - «creador de canciones (inclusive para niños)...»- y a partir de allí se desplegaban las acusaciones, con referencias a una figura de autoridad que las avalaba. Así, el volante intercalaba la mención de que las baladas expresaban «ideas subversivas» y en la siguiente oración postulaba, «Es un apóstol del 'anti-anticomunismo». La corroboración de ello aparecía de manera casi inmediata, cuando señalaba su colaboración en la revista "Tierra Nueva, condenada a fines de 1966 por el Emmo. Cardenal Caggiano, Arzobispo de Buenos Aires y primado de la Argentina». De este modo, los emisores del volante se posicionaban en un lugar de aprobación por contraposición al sacerdote cuestionado. Tras continuar con este tipo de enunciación, en la que la información quedaba ligada de manera directa con la denuncia, el libelo introducía la figura de Mugica con la misma estructura enunciativa. Así, la acción, los posicionamientos y las declaraciones de estos sacerdotes aparecían vinculados con «ideas subversivas», «laicos y

Mundo en Argentina. En particular, Carlos Mujica, quien, proveniente de una familia tradicional, obró como asesor de la Juventud Estudiantil Católica del prestigioso Colegio Nacional de Buenos Aires y de la Juventud Universitaria Católica de la Facultad de Medicina, a través de lo cual entabló contacto con jóvenes que luego participaron del núcleo inicial del grupo guerrillero «Montoneros» -vale aclarar que este sacerdote no participó de esa organización y tampoco avaló la lucha armada-, a la vez que su opción preferencial por los pobres lo llevó a instalarse en una villa de emergencia (asentamiento habitacional precario poblado por sectores carenciados), constituyéndose en un ícono del movimiento de «curas villeros». Martín De Biase, Entre dos fuegos. Vida y asesinato del padre Mugica (Buenos Aires: Ediciones de la Flor, 1998). sacerdotes apóstatas», «ideología progresista extremista», entre otros. Finalmente, la TFP abría un interrogante -lo cual constituía, por el carácter de disyuntiva que planteaba, un llamamiento para el lector-. «Preguntamos al P. Mugica: $¿$ Se ha interesado alguna vez por los derechos de la Iglesia del Silencio, por los derechos humanos de millones de hermanos [...] en todos los países esclavizados por el brutal yugo comunista?» Tras esa pregunta, de carácter cuasi retórico, aparecía la convocatoria como cierre del volante:

ADHIERA PERSONALMENTE AL 'REVERENTE Y FILIAL MENSAJE A SU SANTIDAD EL PAPA PAULO VI' IMPLORÁNDOLE QUE SEA ENTERAMENTE ELIMINADA LA ACCIÓN DE LAICOS Y ECLESIÁSTICOS FAVORABLES AL COMUNismo (mayúscula en el original).

Según la información recabada, estos volantes eran repartidos, mayoritariamente, en los atrios de iglesias céntricas, en avenidas y calles concurridas y en espacios universitarios ${ }^{27}$. De ello pareciera deducirse -teniendo en cuenta, asimismo, el texto producido por la TFP- que los receptores buscados eran tanto los católicos practicantes de sectores acomodados como jóvenes estudiantes, profesionales y sectores medios partícipes de ese credo $^{28}$. Sin desconocer la distancia, siempre presente, entre esa intención de los enunciadores y la realidad fáctica, esta aproximación -de carácter inicial y no concluyente- brinda herramientas para reflexionar sobre las estrategias adoptadas

27 Algunas publicaciones periódicas dieron cuenta de las acciones realizadas por este núcleo en espacios universitarios. «Hubo incidentes en la ciudad de Santa Fe», La Prensa [Buenos Aires], 4 de mayo, 1967, 10; «A la derecha de Dios», Primera Plana [Buenos Aires], 23 de mayo, 1967, 16. También lo señala el sitio web oficial de la TFP Argentina. http://www.pliniocorreadeoliveira. info/GestaES_0201Argentina.htm (consultado el 31 de julio de 2012). Un antiguo militante del Movimiento Nacionalista Revolucionario Tacuara (MNRT) relató la acción pública en las calles de la TFP. Alfredo Ossorio, entrevistado por el autor, Buenos Aires, 28 de octubre, 2011. El padre Pichi destacó el tesón con que eran difundidos en iglesias céntricas. De Titto, por su parte, señaló (a tono con lo señalado usualmente) que la TFP tenía cierta influencia en círculos católicos, militares y de la alta sociedad. De Titto, Voces en las calles, 313.

28 Algunas herramientas para analizar las características de un texto cerrado (que guía al lector hacia una idea determinada, no sujeto a varias interpretaciones y con carácter didáctico) de un emisor (acá, TFP) con miras a llegar a un lector «modelo», así como también la idea del autor que se hace el lector «empírico», en Humberto Eco, El lector modelo (Barcelona: Lumen, 2000). 
por la TFP para difundir sus convicciones y llegar a numerosos sectores de la sociedad civil.

Al mismo tiempo, también otros emprendimientos de filiación católica ampliaban su arenga tendiente a demostrar los vínculos entre el vituperado «progresismo» católico, el comunismo, el marxismo y la subversión. En ocasiones, se trataba de círculos aglutinados en torno a publicaciones periódicas - tal es el caso, por ejemplo, de la revista Roma y, con énfasis variado, de Jauja o Ulises ${ }^{29}$. En otros casos, ese embate se realizaba a través de libros específicos de denuncia -un caso extremo por el tenor de las acusaciones se observa en la obra de Pierre Virion, La masonería dentro de la Iglesia, prologada por el intransigente sacerdote Julio Meinvielle- ${ }^{30}$. Sin embargo, se trataba de impresos de escasa circulación y difusión. En tanto, algunos análisis vertidos en medios de comunicación masiva denotaban los vínculos entre ciertos focos de protesta social y las orientaciones contestatarias de sectores tercermundistas que, día a día, cobraban mayor realce.

\section{Confrontación creciente}

1969 marcó un punto de inflexión en el derrotero de la «Revolución Argentina». La progresiva irrupción de focos de conflicto y el estallido del Cordobazo, en los últimos días del mes de mayo, precipitaron una notable agitación política y social en el país. En este marco, los sectores intransigentes acentuaron su alarma con respecto a lo que consideraban como un avance perentorio de la «infiltración marxista» en diversos espacios de la sociedad, acompañada -según su perspectiva- de la "guerra psicológica» montada por el comunismo para ganar la mente de la población. Así, visiblemente inquietos por el aumento de la protesta social y el despliegue de nuevas prácticas contestatarias, intensificaron sus actividades de denuncia.

29 Sobre Roma, véase Elena Scirica, «Intransigencia y tradicionalismo en el catolicismo argentino de los años sesenta. Los casos de Verbo y Roma», en Los avatares de la nación católica. Cambios y permanencias en el campo religioso de la Argentino contemporánea, ed. Claudia Touris y Mariela Ceva (Buenos Aires: Biblos, 2012), 139-145.

30 Pierre Virion, Misterium iniquitatis. La masonería dentro de la Iglesia (Buenos Aires: Cruz y Fierro, 1968).
El fastidio presente entre diversos núcleos intransigentes, expresado hasta ese entonces de manera algo inconexa o poco articulada, adquirió, pues, un nuevo fervor militante. En este marco se inscribió, por ejemplo, la reacción frente al conflicto generado a fines de 1968, pero con mayor vehemencia el primer semestre de 1969, en la arquidiócesis de Rosario. En la controversia abierta entre el arzobispo Guillermo Bolatti y un importante colectivo sacerdotal que demandaba la introducción de reformas por parte del prelado -evidenciando dos formas distintas de concebir la Iglesia y su relación con el mundo- se involucraron activas agrupaciones católicas y organizaciones laicales. Al mismo tiempo, los panfletos y los medios periodísticos se constituyeron en dispositivos y referentes ineludibles de los actores en conflicto ${ }^{31}$. Desde la perspectiva de algunos sectores comprometidos con la defensa de la autoridad, la tradición y la disciplina, resultaba imperioso desbaratar el plan de «cambiar la Iglesia desde adentro" promovido por ciertos miembros «infiltrados» en la institución eclesiástica. De allí que, en vista de esa acción deletérea llevada a cabo en múltiples frentes, los laicos debían «profundizar su formación religiosa para contrarrestar los sofismas que actualmente se difunden por doquier»y «alentar a los sacerdotes y Obispos fieles a perseverar en su vocación» ${ }^{32}$. Con ese programa de acción salió a la palestra pública el

31 El conflicto de Rosario puede inscribirse dentro del marco de las tensiones intraeclesiales que enfrentaron a obispos y sacerdotes en diversas diócesis en forma paralela y posterior al Concilio Vaticano II. Pero a diferencia de los sucesos de la arquidiócesis de Córdoba, en 1964, o de la de Mendoza, en 1965, los incidentes de Rosario tuvieron una duración y alcances mayores, llegando incluso a la instancia vaticana. Referencia pionera con carga testimonial en Armada; Habegger y Mayol, Los católicos posconciliares. Otra mención comprometida con los hechos desde una óptica opuesta en Carlos Sacheri, La Iglesia clandestina (Buenos Aires: Cruzamante, 1970), Cap. 23. Análisis específico de esos conflictos en Claudia Touris, «Conflictos intraeclesiásticos en la Iglesia argentina posconciliar (1964-1969)», en Los avatares de la nación católica, ed. Claudia Touris y Mariela Ceva (Buenos Aires: Biblos, 2012), 147-179. Ejemplos de la cobertura periodística en la época: «Iglesia, la batalla de Rosario», Primera Plana [Buenos Aires], n. 319,4 de febrero, 1969, 24-27; «Respondieron al arzobispo los treinta sacerdotes renunciantes», La Capital [Rosario], 20 de marzo, 1969, 6; «El conflicto creado en la diócesis de Rosario», La Prensa [Buenos Aires], 24 de marzo, 1969, 5; «Monseñor Bolatti», La Razón [Buenos Aires], 6 de mayo, 1969, 20; «El pleito católico de Rosario», La Razón [Buenos Aires], 27 de mayo, 1969, 12.

32 Sacheri, La Iglesia clandestina, 138 (publicado originariamente en Verbo, n. ${ }^{\circ}$ 96/97, noviembre/diciembre 1969).

E1 grupo «Cruzada» - «Tradición Familia y Propiedad» (TFP) y otros emprendimientos / Elena Scirica / 75 
Movimiento Laico Rosarino, que constituyó una organización de avanzada en la defensa de monseñor Bolatti. Pero tras esa articulación se hallaba el impulso del filósofo Carlos Alberto Sacheri ${ }^{33}$.

Este joven profesor, discípulo de Meinvielle, había retornado a Argentina en 1967, tras concluir su doctorado en la Universidad Laval de Quebec (donde había estrechado vínculos con personas, publicaciones, institutos y otros espacios de socialización de sujetos situados en el horizonte del catolicismo intransigente). Tras su vuelta al país quedó al frente del núcleo contrarrevolucionario $\mathrm{CC}$-estructurado, originariamente, con base en una discreta organización celular orientada a la formación de cuadros posicionados en diversos núcleos de actividad-. Como una organización colateral a la cc, Sacheri organizó el Instituto de Promoción Social Argentina (IPSA) con el propósito de intercambiar experiencias, coordinar obras y aunar esfuerzos de figuras y organismos laicos comprometidos con un «orden social cristiano». En forma paralela ejerció la docencia en la Universidad Católica Argentina (UCA), donde gracias al patrocinio del rector Octavio Derisi dictó numerosas materias. Por otra parte, siempre en consonancia con su estrategia de concertación de obras, entabló vínculos con gremialistas reconocidos - con los que proyectó la formación de escuelas de dirigencia sindical- ${ }^{34}$, a la vez que mantuvo sus ligazones con la Acción Católica de la parroquia del Pilar y con miembros de la parroquia del Carmen, en Buenos Aires. Cabe señalar, finalmente, que gracias a su ascendencia -su padre había sido auditor general de las Fuerzas Armadas- gozó de enorme familiaridad con el espacio castrense $^{35}$. Pero su mayor influjo y protagonis-

33 Sobre Carlos Sacheri retomamos a Hernández, Sacheri. Predicar y morir por la Argentina y, fundamentalmente, sintetizamos el argumento desplegado en Elena Scirica, «Un embate virulento contra el clero tercermundista. Carlos Sacheri y su cruzada contra "La Iglesia clandestina"», en Anuario del Centro de Estudios Históricos Prof. Carlos S. A. Segreti, n. 10 (2010): 283-301.

34 Su principal biógrafo refiere su cercanía con los prominentes dirigentes sindicales José Alonso y José Ignacio Rucci. Hernández, Sacheri. Predicar y morir, 97, 491, 504, 693.

35 Según Ranalletti, «valiéndose de sus lazos familiares, podía franquear las puertas de los cuarteles a piacere, e incluso, utilizar los medios de transporte militares para sus actividades como presidente de "La Ciudad Católica". Mario Ranalletti, «Contrainsurgencia, catolicismo intransigente y extremismo de derecha en la formación militar argentina. Influencias francesas en los orígenes del terrorismo de mo público surgió tras la publicación de La Iglesia clandestina, destinada a la denuncia de los sectores tercermundistas en el país y a constituirse en un faro orientador para el accionar de los laicos.

\section{Una denuncia implacable}

Si bien pueden rastrearse antecedentes previos, los prolegómenos de esa obra surgieron en mayo de 1969. En ese mes no solo se produjo el Segundo Encuentro Nacional del Mstm en la ciudad cordobesa de Caroya, sino que dos semanas después el Episcopado argentino emitió el Documento de San Miguel, orientado a adaptar las resoluciones de Medellín a la realidad del país. A los pocos días, Sacheri publicó una solicitada en La Nación y La Razón del 28 y 29 de mayo de $1969^{36}$. Antes, el 25, había entregado la declaración al cardenal Caggiano, presidente del Episcopado ${ }^{37}$.

La solicitada «A nuestros padres en la fe» exhortaba «a los miembros del Episcopado [a que] ejerzan la plenitud de su autoridad doctrinal y pastoral» para terminar con la «infiltración marxista en los espacios católicos» con su grave correlato -según el autor de la misiva-, en la ola de protesta desatada en Corrientes, Rosario y Córdoba, correspondiente a «un plan subversivo de inspiración marxista, en sincronización con hechos análogos ejecutados a nivel internacional». Acompañando esta visión, Sacheri agregaba que «la autoridad legítima es maestra y responsable tanto de sus decisiones como de sus omisiones», lo que implicaba un firme desafío al cuerpo episcopal.

A partir de entonces - tal como se señaló anteriormente-, la vorágine de las tensiones existentes en el catolicismo junto con el in crescendo de la conflictividad abierta tras el Cordobazo, no hicieron más que contribuir a la radicalización de las posiciones. En estas circunstancias, Sacheri -a través del boletín Verbo, órgano de expresión de la CC- se ocupó de fundamentar su invectiva contra el clero tercermundista.

Estado (1955-1976)», en Terrorismo de Estado y genocidio en América latina, ed. Daniel Feierstein (Buenos Aires: Prometeo, 2009), 267. 36 Carlos A. Sacheri, «A Nuestros Padres en La Fe», La Nación [Buenos Aires], 28 de mayo, 1969 y La Razón [Buenos Aires], 29 de mayo, 1969, 18.

37 Hernández, Sacheri. Predicar y morir, 286. 
La revista de septiembre de 1969 ensalzó la necesaria unidad de la Iglesia en un mundo en el que avanzaba el indiferentismo religioso y la institución eclesiástica se hallaba sometida a una «guerra psicológica» montada por la prensa "progresista». En este marco, Sacheri denunciaba la estrategia oculta, «clandestina», de los «neomodernistas» ${ }^{38}$ para crear una imagen falsa del Concilio valiéndose de múltiples grupos "pseudoproféticos», $\mathrm{y}$ de publicaciones vinculadas entre sí para magnificar esa imagen. Esta última acusación remitía a la difusión de la tarea conciliar realizada por el Centro Internacional de Información y Documentación sobre la Iglesia Conciliar (IDO-C), denunciada por numerosos emprendimientos vinculados con el catolicismo intransigente ${ }^{39}$.

Cabe señalar que en 1969, en forma paralela, la TFP emprendió una vasta campaña contra el IDO-C y «los grupos proféticos [que buscan] hacer de la Iglesia un instrumento de la Revolución Social propiciada por el comunismo» ${ }^{40}$. Esto lo hacían de manera progresiva, pues cobraban mayor realce las distintas iniciativas tendientes a lograr la reprobación y condena del llamado «progresismo».

En su número de diciembre de 1969, Verbo cuestionó el «Manifiesto de los 18 Obispos» por su supuesta imprecisión y tergiversación de ciertas encíclicas papales, y luego encaró una crítica virulenta contra el MSTM y los miembros visibles del grupo, en particular, Miguel Ramondetti. Según Sacheri, el mstm tenía una estructura clandestina -por el anonimato de sus integrantes, la no explicitación de sus objetivos y su cuestionable

38 La alusión al «neomodernismo» remite a las tesis modernistas de fines del siglo $x I x$ y comienzos del siglo $x x$, según las cuales la Iglesia y sus dogmas son instituciones humanas y -como talestienen un carácter histórico; estas reflexiones fueron condenadas por el Papa Pío x, en su encíclica Pascendi (1907). Algunos sectores del catolicismo consideraron que las tesis modernistas y su «Nueva Teología» pervivieron agazapadas hasta la convocatoria al Concilio Vaticano II, en el que lograron insertarse e, incluso, en algunos casos, trasladaron su mirada secularizante desde el plano dogmático y doctrinario hacia el social. Esa denuncia correspondió a los sectores más refractarios a cualquier tipo de apertura y diálogo con el mundo moderno, frente al cual ensalzaron una perentoria cristianización de la sociedad.

39 La denuncia contra el IDO-c fue publicada originariamente en la revista inglesa Approaches y luego por la francesa Permanences. En Argentina, fue dada a conocer por la publicación Roma: «Qué es el IDO-C», Roma, n. 7 (1968): 46-66 y luego por Tradición, familia y propiedad, n. ${ }^{\circ} 4-5$, junio-julio (1969).

40 Volante de TFP. metodología, propia de la «estrategia comunista»- que apuntaba a la destrucción del orden social. De allí la necesidad de que las autoridades eclesiásticas impusieran la disciplina con rigor y de que los laicos profundizaran su formación y denunciaran al nuevo «clericalismo» ${ }^{41}$.

Estas alocuciones, pues, presentaban una denuncia concreta, elaborada a partir de un planteo teológico sencillo y de una fuerte carga maniquea. Además, el aporte de datos puntuales y las alusiones a personas específicas brindaban certezas y puntos de referencias claros para los receptores de la crónica. Al mismo tiempo, tanto su apelación directa a la jerarquía eclesiástica, como su requerimiento a los laicos católicos para que asumieran las responsabilidades que los tiempos demandaban, situaban a los interpelados en un lugar activo propicio para la adopción de decisiones. De este modo, cuando en 1970 las distintas entregas vertidas el semestre anterior en Verbo se estructuraron en el libro La Iglesia Clandestina, la obra tuvo una repercusión notable (en 1970 tuvo tres impresiones, en abril, octubre y noviembre, seguida por una cuarta en enero de 1971). En este sentido, este impreso tuvo un rol protagónico en la denuncia del MSTM frente a la opinión pública católica. A ello contribuyeron, por supuesto, las propias vicisitudes del derrotero político, social, ideológico y religioso en el país. Pero no por eso deben desestimarse las estrategias desplegadas para "pulsar» el sentido de las apreciaciones hacia aquel colectivo sacerdotal. La primera impresión del libro no solo fue contemporánea con la creciente conflictividad, sino también con la designación de monseñor Adolfo Tortolo al frente de la Conferencia Episcopal. El nombramiento de este prelado, reconocido por su vínculo con las Fuerzas Armadas y por su posición claramente opuesta a las nuevas tendencias, evidenciaba el intento de reimposición de la autoridad en las filas eclesiásticas ${ }^{42}$, a la cual «La Iglesia Clandestina» pretendía apuntalar. Para ello, Sacheri desplegó una labor incansable, que incluyó -junto con la prédica en el

\footnotetext{
41 Verbo, n. ${ }^{\circ}$ 96/97, noviembre/diciembre (1969): 6-52.

42 Martín Obregón, Entre la cruz y la espada. La Iglesia católica durante los primeros años del «Proceso» (Bernal: Universidad Nacional de Quilmes, 2005), 34-36.
} 
ámbito castrense- charlas en clubes y asociaciones barriales, en centros municipales, en colegios católicos, en organizaciones estudiantiles, en debates televisivos e incluso con dirigentes sindicales, acompañada por múltiples menciones en la prensa periódica, que así amplificaba su $\mathrm{voz}^{43}$. También hizo lo propio en el marco de su docencia universitaria en la UCA y la UBA. La meta no era, claro está, el libro en sí, sino la instalación de la denuncia. En este sentido, su compenetración con la necesidad de "ganar la mente» de la población jugó un papel central. En forma correlativa, el secuestro y asesinato del general y ex presidente de la nación Pedro E. Aramburu, seguido por la acusación de lazos entre el MSTM y los perpetradores de ese acto, generaron un espacio perceptivo propicio para la amplificación de la denuncia contra la «Iglesia Clandestina». La ocasión fue aprovechada, a su vez, por un grupo de eclesiásticos opuestos a esa tendencia para emitir un documento sumamente crítico de los tercermundistas, que fue enviado al arzobispo de Buenos Aires y a otros prelados ${ }^{44}$.

En forma coetánea, los miembros de la TFP, en el marco de sus continuas campañas, distribuían volantes en los que también denunciaban los vínculos entre el MSTM, el renombrado asesinato y el estrepitoso accionar guerrillero en la localidad

43 Seleccionando al azar algunas notas de julio y agosto de 1970 , en La Razón [Buenos Aires], a la sazón el vespertino de mayor circulación en el país, se observa su disertación en el Colegio San José, «Estamos ante la Iglesia clandestina», 25 julio, 1970, 4; su Conferencia en la parroquia del Pilar, en «La Iglesia clandestina», 14 agosto, 1970, 6; sobre el segundo congreso del IPSA, la crisis de autoridad y los deberes del laico, «El laico y la Iglesia», 18 agosto, 1970, 16; su participación en mesa redonda de la UCA, «¿Radiografía de los montoneros?», 15 agosto, 5. Otras notas coincidentes con la denuncia emprendida, del cardenal Danielou que condena la herejía, «Habla un cardenal», 27 julio 1970, 3; denuncia del grupo Misión, «Una difícil situación se ha creado en nuestra Iglesia», 28 de julio, 1970, 1; grupo de laicos contra el sociologismo subversivo y el MSTM, «Una declaración», 5 agosto, 1970, 12. Una conferencia de Sacheri en entidades de salud y beneficencia en Córdoba, «La Iglesia en el mundo actual», Córdoba, 4 setiembre, 1970, 7. Según Patricio Randle, disertó en la Escuela de Inteligencia de la Armada y del Ejército, Hernández, Sacheri. Predicar y morir, 95. En 1972, el diario correntino La Mañana reprodujo los artículos de Sacheri. Gracias a su amistad con Diana Julio de Massot, La Nueva Provincia [Bahía Blanca] también lo publicitó. En esta suerte de «cruzada», Sacheri organizó un debate contra el clero tercermundista en un programa televisivo de su conocido Mariano Grondona. Hernández, Sacheri. Predicar y morir, 323-324.

44 «Declaración de sacerdotes argentinos», incorporada -a partir de su segunda impresión- en el anexo documental de La Iglesia clandestina. También en La Razón [Buenos Aires], 1 agosto, 1970, 4. cordobesa de La Calera -el 1 de julio de 1970, el grupo Montoneros tomó la comisaría, asaltó el Banco de la Provincia de Córdoba, y copó la central telefónica de esa localidad, aunque posteriores errores en la retirada derivaron en la detención de varios de sus militantes-. A partir de ello, el panfleto señalaba los movimientos u organizaciones solidarizados «con la actitud revolucionaria violenta de los acusados» y puntualizaba la responsabilidad expresa del "progresismo», en tanto «la doctrina es el antecedente necesario de los hechos y [...] la Revolución Sofística precede a la Revolución práctica». Por lo tanto, el impreso realizaba una firme amonestación:

Frente a la situación existente, cualquier medida será inútil, mientras la jerarquía eclesiástica no extermine la obra del mal imponiendo la cesación de las ideologías subversivas en los ambientes católicos, con ejemplar castigo de los culpables. La Historia juzgará severamente la actitud enigmática de los Obispos que pudieron corregir todo esto e inexplicablemente se cruzaron de brazos ${ }^{45}$.

De forma concurrente -aunque no necesariamente articulada- altos funcionarios gubernamentales tuvieron encuentros reservados con los miembros de la Comisión Ejecutiva del cuerpo episcopal. ${ }^{46}$ Justamente en esos días se reunía la Comisión Permanente del Episcopado y -como era esperable-el 12 de agosto de 1970 emitió una declaración admonitoria hacia los curas rebeldes.

\section{Corolarios y consideraciones finales}

Alentados por esa contraofensiva, algunos sectores pertenecientes al campo del catolicismo intransigente redoblaron sus apuestas tendientes a ganar la batalla en la conciencia de la grey católica. En este marco se inscribió, por ejemplo, la elaboración y distribución vía postal, sin cargo, de un extenso folleto de 60 páginas, rotulado: Movimiento de Sacerdotes

45 Volante «Diálogo Directo de la TFP con el público argentino», Buenos Aires, 6 de agosto, 1970.

46 La Razón rotuló una de sus tiradas: «Desde las más altas esferas se ha hecho llegar una profunda preocupación a la Iglesia, que la semana próxima se propone encarar la situación», La Razón [Buenos Aires], 30 de julio, 1970, 1. Dos días después, la portada de ese periódico incluía los títulos «El gobierno encara la agitación subversiva» $\mathrm{y}$ «60 sacerdotes elevarán una nota al Arzobispado», La Razón [Buenos Aires], 1 agosto, 1970, 1. 
para el Tercer Mundo. ¿ंGuerrilleros o misioneros? ¿Es un Movimiento Politico, Social, Espiritual o Subversivo? Aclare sus dudas leyendo diversas opiniones ${ }^{47}$.

Este folleto constaba de una introducción, catorce artículos -seleccionados de distintas revistas y periódicos de alcance nacional- $\mathrm{y}$ unas reflexiones finales. Con una apelación clara al lector, a quien se invocaba como «compatriota»-asimilando, así, la población católica con la de la patria- y bajo un supuesto manto de transparencia, ya que afirmaba dejar en manos del lector interpelado la interpretación del verdadero sentido del MSTM, el impreso dejaba ver -a través de recuadros de presentación de los artículos o con la inserción de acotaciones al final de estos- la «demagogia», «falsedad conceptual» y las «interpretaciones extremas de la doctrina cristiana» que alimentaban el «terrorismo». Asimismo, la selección de notas buscaba contraponer las declaraciones de la jerarquía eclesiástica con las de este colectivo sacerdotal, sobre el cual se remarcaba -en las reflexiones de cierre- que ha «optado por el cambio a la violencia, a la guerrilla, al crimen y al terrorismo».

El armado y difusión de este cuadernillo evidencia el despliegue de una estrategia potente $-y$ onerosa- destinada a contrarrestar el influjo del MSTM. En este sentido, las nuevas y creativas formas de reclamo y participación emprendidas por los sectores tercermundistas -expresadas en comunicados, declaraciones, distribución de volantes, ayunos, ollas populares, ocupaciones de espacios, entre otras- dieron lugar a la organización de dispositivos para contrarrestarlos. Pero si bien estas respuestas se ubicaron en un terreno de disputa que aparentemente se libraba en el mismo plano -artilugios orientados al convencimiento-, en última instancia nunca dejaron de apelar a la denigración y al ejercicio de la autoridad y de la fuerza. De hecho, el folleto reseñado planteaba, entre los interrogantes de cierre:

47 El folleto estaba firmado por el Movimiento de Unidad Nacional -sobre el cual no se poseen referencias- y, según los sacerdotes Domingo Bresci y José María Meisegeier (Pichi), tuvo una difusión importante en Buenos Aires y en el resto del país. El cuadernillo venía acompañado por una pequeña nota de dos párrafos en la que se señalaba el envío sin cargo «con la finalidad de esclarecer uno de los tantos problemas que nos preocupaban a los argentinos» aunque también dejaban abierta la posibilidad de abonar un importe en caso de requerir nuevas copias y así ayudar con la financiación de los gastos.
¿Piensa Ud. que la acción social que eventualmente pudiera realizar la Iglesia en el orden temporal, solo puede lograrse por la incitación a la violencia, la intervención y defensa de todo disturbio contra las autoridades de cualquier tipo [...], el apoyo material $\mathrm{y}$ espiritual a las guerrillas, a los asaltantes, secuestradores e incluso asesinos en banda? [...]. ¿Qué haría usted si fuera gobernante?, ¿Cree Ud. que la difusión de tal declaración [del Episcopado] es suficiente para contrarrestar la acción subversiva y disolvente del Movimiento? ¿Piensa que deben tomarse otras medidas más concretas contra sus integrantes? ${ }^{48}$.

De estos interrogantes puede deducirse que, en definitiva, al menos en este caso, la apelación a la opinión pública católica no buscaba quedarse en el mero plano del convencimiento sino, más bien, pretendía obtener apoyos -o, al menos, aceptación- para librar un embate definitivo, no exento de coerción, contra el MSTM.

\section{Bibliografía}

\section{Fuentes primarias}

«60 sacerdotes elevarán una nota al Arzobispado». La Razón [Buenos Aires], 1 agosto, 1970, 1.

«A la derecha de Dios». Primera Plana [Buenos Aires], 23 de mayo, 1967, 16-17.

«Católicos. Colaboración con el gobierno». Primera Plana [Buenos Aires], 12 de julio, 1966, 14.

«Covadonga, ¿̇monumento a una epopeya negativista?». Verbo, n. ${ }^{\circ}$ 61-62 (junio/julio 1966): 25-30.

«Declaración de sacerdotes argentinos». La Razón [Buenos Aires], 1 agosto, 1970, 4.

«Desde las más altas esferas se ha hecho llegar una profunda preocupación a la Iglesia, que la semana próxima se propone encarar la situación». $L a$ Razón [Buenos Aires], 30 de julio, 1970, 1.

«El conflicto creado en la diócesis de Rosario». $L a$

Prensa [Buenos Aires], 24 de marzo, 1969, 5.

«El gobierno encara la agitación subversiva». La Razón [Buenos Aires], 1 agosto, 1970, 1.

«E1 laico y la Iglesia». La Razón [Buenos Aires], 18 agosto, 1970, 16.

«El pleito católico de Rosario». La Razón [Buenos Aires], 27 de mayo, 1969, 12.

\footnotetext{
48 Movimiento de sacerdotes para el tercer mundo. ¿Guerrilleros o misioneros? ¿Es un movimiento político, social, espiritual o subversivo? Aclare sus dudas leyendo diversas opiniones. Buenos Aires, Septiembre, 1970, 60.
} 
«Estamos ante la Iglesia clandestina». La Razón

[Buenos Aires], 25 julio, 1970, 4.

«Hubo incidentes en la ciudad de Santa Fe». La

Prensa [Buenos Aires], 4 de mayo, 1967, 10.

«Habla un cardenal». La Razón [Buenos Aires], 27 julio 1970, 3 .

«Hubo incidentes en la ciudad de Santa Fe». La

Prensa [Buenos Aires], 3 de mayo, 1967, 10.

«Iglesia, la batalla de Rosario». Primera Plana [Buenos Aires], n. ${ }^{\circ} 319,4$ de febrero, 1969, 24-27.

«Interpelación a los actuales dirigentes del peronismo».

La Nación [Buenos Aires], 20 de agosto, 1965: 5

«Introducción de 'Revolución y contrarrevolución'».

Verbo, n.o 3 (julio 1959): 52-56.

«La Iglesia clandestina». La Razón [Buenos Aires],

14 agosto, 1970, 6.

«La Iglesia en el mundo actual». Córdoba [Córdo-

ba], 4 setiembre, 1970, 7 .

«La Iglesia y el cambio social». La Nación [Buenos

Aires], 8 de septiembre, 1965: 3

«Los católicos y el poder». Primera Plana [Buenos

Aires], 16 agosto, 1966, 16-21.

«Monseñor Bolatti». La Razón [Buenos Aires], 6

de mayo, 1969, 20.

"Qué es el IDO-C». Roma, n. 7 (1968): 46-66.

"Qué es el IDO-C». Tradición, familia y propiedad, n. ${ }^{\circ}$ 4-5 (junio-julio 1969).

«Radiografía de los montoneros?». La Razón [Buenos Aires], 15 agosto, 5 .

«Respondieron al arzobispo los treinta sacerdotes renunciantes». La Capital [Rosario], 20 de marzo, 1969, 6.

«Una declaración». La Razón [Buenos Aires], 5 agosto, 1970, 12.

«Una difícil situación se ha creado en nuestra Iglesia». La Razón [Buenos Aires], 28 de julio, 1970, 1.

Volantes de TFP

Folleto del Movimiento de Unidad Nacional

Armada, Arturo; Norberto Habegger y Alejandro Mayol. Los católicos posconciliares en la Argentina. Buenos Aires: Galerna, 1970.

Correa de Oliveira, Plinio. Trasbordo ideológico inadvertido y Diálogo. Buenos Aires: Cruzada, 1966.

Sacheri, Carlos. La Iglesia Clandestina. Buenos Aires: Cruzamante, 1970.

\section{Entrevistas}

Osorio, Alfredo. Entrevistado por el autor. Buenos Aires, 28 de octubre, 2011.
Documentos electrónicos

La TFP en combate contra la ambigüedad y el caos ideológico-político que impiden a la nación alcanzar su destino de grandeza cristiana. www.pliniocorreadeoliveira.info/GestaES_0201Argentina.htm.

Tradición, familia y propiedad. http//www.pliniocorreadeoliveira.info/GestaES_0000Indice.htm

\section{Fuentes secundarias}

Bett, Ianko. «Una revolución que nos afecta: A Revista Cruzada e o golpe militar de 1964 no Brasil». En Actas de las Terceras Jornadas de Religión y Sociedad en la Argentina contemporánea y países del Cono SUr (III RELIGAR-SUR) -RELIG-AR SUR V Jornadas de Religión y Sociedad en Argentina, editado por Claudia Touris y María Florencia Contardo. Buenos Aires: RELIG-AR ediciones, 2013.

Dalmazo, Gustavo. «El tradicionalismo ante la apertura política en la Revolución Argentina». En IV Jornadas Nacionales de Historia Moderna y Contemporánea. Resistencia: Universidad Nacional del Nordeste, 2004.

De Biase, Martín. Entre dos fuegos. Vida y asesinato del padre Mugica. Buenos Aires: Ediciones de la Flor, 1998. De Titto, Ricardo. Voces en las calles. Los volantes politicos en la historia argentina. Buenos Aires: Aguilar, 2007.

Di Stéfano, Roberto y Loris Zanatta. Historia de la Iglesia Argentina. Buenos Aires: Grijalbo Mondadori, 2000.

Eco, Humberto. El lector modelo. Barcelona: Lumen, 2000.

Esquivel, Juan Cruz. Detrás de los muros. La Iglesia católica en tiempos de Alfonsin y Menem. 19831999. Buenos Aires: Universidad Nacional de Quilmes, 2004.

García Lupo, Rogelio. «Los Cursillos de Cristiandad: partido secreto de Onganía». En Mercenarios y monopolios en la Argentina. De Onganía a Lanusse: 1966-1973, editado por Rogelio García Lupo, 11-27. Buenos Aires: Legasa, 1984.

Hernández, Héctor. Sacheri. Predicar y morir por la Argentina. Buenos Aires: Vórtice, 2007.

Lewis, Paul. «La derecha y los gobiernos militares. 1955-1983». En La derecha argentina. Nacionalistas, neoliberales, militares y clericales, ed. David Rock et al., 321-370. Buenos Aires: Javier Vergara, 2001. 
Mallimaci, Fortunato. El catolicismo integral en la Argentina. 1930-1946. Buenos Aires: Biblos, 1988.

Mattei, Ricardo. El cruzado del siglo Xx. Plinio Correa de Oliveira. Madrid: Ediciones Encuentro, 1997.

Obregón, Martín. Entre la cruz y la espada. La Iglesia católica durante los primeros años del «Proceso». Bernal: Universidad Nacional de Quilmes, 2005.

Ranalletti, Mario. «Contrainsurgencia, catolicismo intransigente y extremismo de derecha en la formación militar argentina. Influencias francesas en los orígenes del terrorismo de Estado (19551976)». En Terrorismo de Estado y genocidio en América Latina, editado por Daniel Feierstein, 249-280. Buenos Aires: Prometeo, 2009.

Rouquié, Alain. «La tentación del catolicismo nacionalista en la República Argentina». En Autoritarismo y democracia. Estudios de politica argentina, editado por Alain Rouquié, 83-139. Buenos Aires: Edicial, 1994.

Rouquié, Alain. Poder militar y sociedad política en la Argentina.T. Ir. Buenos Aires: Hyspamérica, 1986.

Scirica, Elena. «Intransigencia y tradicionalismo en el catolicismo argentino de los años sesenta. Los casos de Verbo y Roma». En Los avatares de la nación católica. Cambios y permanencias en el campo religioso de la Argentino contemporánea, editado por Claudia Touris y Mariela Ceva, 129-146. Buenos Aires: Biblos, 2012.

Scirica, Elena. «Núcleos católicos anticomunistas bajo el Onganiato. Encuentros y desencuentros». En Primer Taller de Análisis y discusión sobre el Onganiato, editado por Florencia Osuna y Valeria Galván. Los Polvorines, Prov. de Buenos Aires: Universidad Nacional de General Sarmiento, 2012.

Scirica, Elena. «Un embate virulento contra el clero tercermundista. Carlos Sacheri y su cruzada contra «La Iglesia clandestina». Anuario del Centro de Estudios Históricos Prof. Carlos S. A. Segreti, n. 10 (2010), 283-301.

Scirica, Elena. «Visión religiosa y acción política. E1 caso de Ciudad Católica-Verbo en la Argentina de los años sesenta». PROHAL monográfico, Revista del Programa de Historia de América Latina. Vol. 2. Primera sección: Vitral Monográfico, n. ${ }^{\circ}$ 2. Instituto Ravignani, Facultad de Filosofía y Letras, uBA, Buenos Aires (2010): 26-56.
Touris, Claudia. «Conflictos intraeclesiásticos en la Iglesia argentina posconciliar (1964-1969)». En Los avatares de la «nación católica». Cambios y permanencias en el campo religioso de la Argentina contemporánea, editado por Claudia Touris y Mariela Ceva, 147-179. Buenos Aires: Biblos, 2012. Touris, Claudia. «Integrismos y profecía utópica en los imaginarios católicos de los años setenta». En Nuevos aportes a los estudios de la religión en las sociedades contemporáneas del Cono Sur, editado por Mariela Ceva y Claudia Touris, 101-115. Buenos Aires: Lumiere, 2011.

Touris, Claudia. «Sociabilidad e identidad político-religiosa en los grupos católicos tercermundistas en la Argentina (1966-1976)». En Miradas sobre la bistoria social en la Argentina en los comienzos del siglo XXI, editado por Beatriz Moreyra, y Silvia Mallo, 763-783. Córdoba - La Plata: Centro de Estudios Históricos «Prof. Carlos S. A. Segreti». Centro de Estudios de Historia Americana Colonial-CEHACFacultad de Humanidades y Ciencias de la Educación. Universidad Nacional de La Plata, 2008.

Verbitsky, Horacio. La violencia evangélica. Buenos Aires: Sudamericana, 2008.

Zanatta, Loris. Del Estado liberal a la nación católica. Bernal: Universidad Nacional de Quilmes, 1996. Zanca, José. Los intelectuales católicos y el fin de la cristiandad. 1955-1966. Buenos Aires: Fondo de Cultura Económica-Universidad de San Andrés, 2006.

Zanotto, Gizele. Tfr. Tradição, Família e Propiedade. As idiosincrasias de um movimento católico no Brasil,1960-1995. Passo Fundo: Méritos Editora, 2012.

Fecha de recepción: 27 de julio de 2013

Fecha de evaluación: 1 de septiembre de 2013

Fecha de aprobación: 1 de octubre de 2013

\section{Cómo citar este artículo}

Scirica, Elena. «El grupo "Cruzada”-"Tradición Familia y Propiedad" (TFP) y otros emprendimientos laicales tradicionalistas contra los sectores tercermundistas. Una aproximación a sus prácticas y estrategias de difusión en los años sesenta». Memoria y sociedad 18, n. 36 (2014): 66-81. http://dx.doi. org/10.11144/Javeriana.MYS18-36.gctf 